\title{
REVISITING POLITICAL THEORY: BEYOND EXCESSIVE EMPIRICISM AND EXTREME NORMATIVISM
}

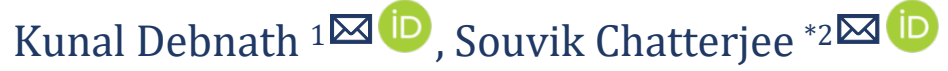 \\ ${ }^{1}$ Department of Political Science, Rabindra Bharati University, Kolkata - 700050, India \\ *2 Department of Politics and International Relations, Central University of Jharkhand, India
}

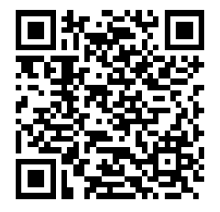

DOI: https://doi.org/10.29121/granthaalayah.v9.i3.2021.3743

Article Type: Research Article

Article Citation: Kunal Debnath, and Souvik Chatterjee. (2021). REVISITING POLITICAL THEORY: BEYOND EXCESSIVE EMPIRICISM AND EXTREME NORMATIVISM. International Journal of Research GRANTHAALAYAH, 9(3), 47-55. https://doi.org/10.29121/granthaa layah.v9.i3.2021.3743

Received Date: 25 February 2021

Accepted Date: 20 March 2021

Keywords:

The Political

Empirical

Normative

Theory

Contestability

Post-Factual Politics

\begin{abstract}
In this paper we attempt to find an answer to the question - how can we revisit political theory? This question may seem apparently simple, but the moment one start exploring, the incongruities and complexities of politics make the undertaking question highly toilsome. It is impossible to completely reject the normative framework in political analyses as far as it deals with the human society. On the other side, the age of post-truth politics also creates a difficulty to find out the objective facts and truth. So rather than arguing which method of politics is more efficient to deal with the uncertainties of human political life today, we attempt to visualize politics from a new understanding i.e., politics as absence of general agreement beyond excessive empiricism and extreme normativism. It is the antagonistic nature of human beings what keep 'the political' alive, and constitute the factual practices known as 'politics'.
\end{abstract}

\section{INTRODUCTION}

In order to find out the substance of politics and what are the prerequisite of a good political analysis, both political scientists and theorists made numerous attempts and their viewpoints and methodologies differ significantly from one another. Political scientists disapprove the views of political theorists for their lack of factualism and proper standards to steer politics scientifically into a new direction. Political theorists, on their part, argue for a political analysis that aims to produce a new normative knowledge of politics. It is argued that the deficiency of interpretative studies is that it does not add something novel to the discipline because its claims cannot be verified or testified by applying scientific methods. Political theorists respond by arguing that unlike scientists who discover new factual knowledge, theorists engage in advances of interpretations that allow a discipline to explain more coherently about a set of facts that are already known. It seems an appropriate time to take stock of how we access political theory, its features and nature of politics in this new century. Although this article briefly explores the weakness of both method-driven and theory-driven approach of politics and their implications in politics. It is an attempt to understand politics from a new perspective in this age of uncertainty.

(C) 2021 The Author(s). This is an open access article distributed under the terms of the Creative Commons Attribution License, which permits unrestricted use, distribution, and reproduction in any medium, provided the original author and source are credited. 
Revisiting Political Theory: Beyond Excessive Empiricism and Extreme Normativism

Yet although this essay is partially cognate with the historical pragmatics, this essay never argues what method deals politics more efficiently. Rather we attempt to visualize politics from a new understanding i.e., politics as absence of general agreement. In this study we take politics as means to understand how society is organised, what are the operating principles of society and whether perfect harmony and absolute social co-operation is ever possible or not.

It is often argued that political theory is rather an ambiguous term in the discipline Political Science as political theory is claimed by both the philosophical and scientific practitioners. While philosophical indicates the normative political theory, scientific refers to the empirical political theory. Still ambiguity persists over the name of the discipline political science as the term 'science' is pretty problematic here. If here science implies the scientific understanding of politics, it uncovers some vital questions; does this discipline enquire scientifically the nature and practices of politics adopting the methods based on quantification, verification, measurement, observation, description, etc., or does only the scientific explanation explore adequately the nature and practices of politics in local or national or international level, or does only the empirical data explain the essence of 'the political'? Even it unveils another questions that whether the scientific generalisation is fully applicable in understanding the nuances of politics, or is any theoretical understanding needed for analyzing the essence of 'the political'?

In this essay we intend to underline some methodological shades curious to how we will understand and analyse the underlying structure of 'the political'. Also this essay encapsulates why fully empirical study, discerning the human's innate dimensions, is incapable of capturing the core of 'the political'. This essay, however, does not fully ignore the empirical study. Though this essay is not exclusively for the researchers of political science, yet we propose that every political research should also be capable of capturing the nuances of 'the political', which are shaped largely by the antagonistic nature of the human beings. This essay also focuses on the nature of 'the political' that demands a deeper understanding for explaining the empirical political reality, rather than merely explaining the fact and data collected and interpreted with the help of some 'designated' software. Finally, this article argues, the conception of objective facts and truth is also contested in contemporary political context. So it remains clear that both theorists and scientists have been keen on understanding the true nature of politics since time immemorial. Therefore, anyone may ask what is new that we attempt to uncover in this article. In this article we attempt to explore three questions: Why is political theory still relevant? How it can help us to understand the contemporary world? And is there any alternative way to theorize politics beyond empiricism and normativism.

\section{2. 'POLITICS' AND 'THE POLITICAL'}

The very reason why use of methodology of natural sciences is inapplicable to the study of social sciences, in the natural sciences they tend to focus on objectivity and generalization but in social sciences there are no such things as universal laws or principles that will be applicable in all over the world in a uniform way. Social sciences deal with human beings who are self-evaluative in nature, they learn from their historical past and act themselves in the changing situations. But in natural sciences if certain steps are followed carefully it will always yield similar results. It is well accepted that while the natural world continues independently of human being, the human world is largely instituted on human action which is unpredictable. Explanation always finds regularity to enquire not only the past but also the future. In other words, modern empirical sciences search for explaining the future through prediction (Bhargava, 2012). While the physical world can exist without any conceptual schema, the human world is profoundly conceptual since human beings do not merely live and sense it, but always try to create images, concepts, understand, and interpret the experiences. Human beings live in, what philosopher Husserl (1970) says, the 'life world' and plucking the vocabulary of philosopher Wilhelm Dilthey we might say this experience as 'lived experience'. Dilthey argued for hermeneutics to comprehend the interpretations of human experiences and historical texts of human life. The word hermeneutics is derived from the Greek god Hermes, a deity of speech and writing. Dilthey strongly rejected in using a model formed exclusively for natural sciences, and instead proposed developing a separate methodology for human sciences. His argument centered around the idea that in the natural sciences we seek to explain phenomena in terms of cause and effect, in the human sciences, contrarily, we seek to understand and interpret the phenomena. In other words, while nature offers a field of explanation, humanity offers a field of understanding, in German what is called 'Verstehen' and which is based on the 'lived experience'. Dilthey wrote, "understanding of other people and their expression is developed on the basis of experience and selfunderstanding and the constant interactions between them" (As cited in Thiele, 2002, p. 16). We can find two 
conclusions from Dilthey - firstly, distinction between human sciences and natural sciences. In the domain of nature, the rules are same, but in human society the rules vary over the time and space. Secondly, there is a difference between explanation and understanding. Since human beings are unpredictable then social sciences should not be describing or explaining in method. It should be understanding and interpreting. Thus political theory is often assumed a hermeneutic experience and political theorists are termed hermeneuts who interpret events grounding in 'the political'. Auguste Comte, the founding figure of sociology and pioneer of positivism, himself insisted that "no real observation of any kind of phenomenon is possible, except in as far as it is first directed, and finally interpreted, by some theory" (As cited in Thiele, 2002, p. 2). In social sciences, values and theorists' own experiences indeed play an important role. For example, if we do not understand or have experienced certain conceptions of justice how can we assess a fact as whether it is just or unjust? If we distinguish between good or bad, we must have certain notion of good and bad and here theories play an important role in shaping individual preferences and their understanding of the social world. Indicating the limits of the translated works on Dilthey, Makkreel and Rodi (1996) prefaced in the 'Selected Works of Wilhelm Dilthey' as "Dilthey's overall position was more flexible than has been realised. His distinction between understanding (Verstehen) and explaining, for example, was not intended to exclude explanations from the human sciences, but only to delimit their scope (p. viii)".

As far as verstehen is concerned, Weber (1949) argues that all the sciences of psychological and social phenomena are science of human conduct including thoughts and attitudes of human beings, and "these sciences seek to 'understand' this conduct and by means of this understanding to 'explain' it 'interpretatively'” (Weber, 1949, p. 40). In Politics, however, we do not only explain certain political realities only on the basis of the empirical evidences, but we explore and interpret these political realities on the basis of theory. Notwithstanding explanation is crucial, but all theories are not explanatory and explanation is not the whole, but a part of political theory (Bhargava, 2012). This does not mean that we are free from biases but our goals should be that we must understand our biases and try as far as possible to develop a systematic body of work. In the twentieth century, due to remarkable transformation in both social as well as natural sciences research and with the development of falsification, the members of scientific community came into conclusion that only verification could not be regarded as the sole criterion of scientific knowledge because it is an ongoing process. So, going beyond causality as the only accepted method of verifying hypothesis, we should also give a due place to the alternative models, like reason-action explanation, narrative mode and hermeneutic understanding (Mahajan, 2011). Even in an explanation, the observer must validate his claims by interpreting his outcomes and infer whether the outcomes are in accordance with his hypothesis that are conceptualised based on certain theoretical understanding or not. Once we started to consider interpretation and presence of theory as a condition rather a limitation we can overcome and even develop a truly scientific body of knowledge that will make a bridge between methodologies of natural sciences with the normative framework upon which the whole human sciences rest. Mere facts or information do not define or explain themselves, we need a framework of analysis that is constructed by theories that explain and provides meaning of the facts and makes these facts significant to discuss, evaluate, and deliberate about any social phenomenon. The relationship between theory and reality is an essential and complementary one. It is the theory or conceptual schema that provides the foundation that helps to evaluate the political reality easily, in return the evaluation helps to broaden the horizons of theory. As "it is impossible to understand thought or action or work without evaluating it. If we are unable to evaluate adequately, as we very frequently are, we have not yet succeeded in understanding adequately" (Strauss, 1988, p. 21).

\section{METHODOLOGICAL MISCONCEPTIONS IN UNDERSTANDING 'THEORY’}

Theories have its own primacy in human sciences and even in natural sciences also what is often missed out by many. Question may arise that is it even possible for natural sciences to completely be value free? Or, what is the role of normative dimension in the discipline of natural sciences? Referring to the second question the major crux of any scientific study is the development of certain principles on the basis of which it tries to make generalization but the question remains when a scientist develops a set of hypothesis, is it totally free from his own value preferences? The similar question may be asked that why a specific object of the natural world attracts the researcher to conduct analysis? Can we conceive it without understanding one's own value preferences? This parochial and narrow centric understanding of natural sciences, as Lekka-Kowalik (2010) critiques, lies in the fact that when natural sciences start to take values into account, it essentially constitutes an example of bad science due to the fact that natural sciences 
as a whole refers to an objective and value free analysis and understanding of the natural world that strives for developing certain set of rules with universal applicability. In spite of natural sciences' too much emphasis upon this empirical side, even in reality, it is not possible to develop a systematic and scientific study while totally neglecting innate value preferences. Science in general is seen as a set of means or tools by which certain goals are achieved. These goals are essentially determined by the societal needs. The tasks of science are to efficiently achieve that goals in a more convenient way. But among several goals what goals require an urgent scientific remedy, here lies the value preferences. Similarly the question of ethics and morality, both are essentially value laden, become too much apparent in case of misuse of science and technology. We often heard the phrase that is science a 'boon or blessing'? It implies, in spite of too much emphasis on 'objectivity', science have a responsibility towards the well-being and good of the society. Lekka-Kowalik (2010) highlights an interesting area of value laden aspects of science. She identifies the role of scientific expertise in public-policy decision making where scientists must rely on certain choices, those choices range from using appropriate methodologies to interpret their findings effectively. This becomes even more apparent when they have to justify their outcomes by underlining why alternative choices are not feasible. But unfortunately we lay more emphasis on the findings rather than those of choices which are essentially moulded by one's own preferences. So in short, as long as science has a progressive role to play in development of human race, it may claim for complete objective analysis but in reality natural sciences are not completely free from value preferences. The problem is that how we interpret the essence of science. Values in natural sciences are not explicit per se, they are moreover latent and implicit in nature that does not imply science is essentially value-free.

\section{UNDERSTANDING 'THEORY' IN 'POLITICAL THEORY’}

From the very beginning, political theory has been misinterpreted that it prescribes more or speculates much rather than comprehend the actual political realities. But this view is essentially mistaken one. The actual connotation of 'theory' is often miss-employed when we use the term 'political theory'. This trend has been in vogue since the nineteenth and twentieth centuries that it is being used pejoratively as corresponding to what Vincent (2007) identifies as 'mere speculation' or 'untested facts'. However, the word 'theory' derived from the Greek words 'theoros', one who performs as an envoy, and 'theoria', the activity of theoros. Both 'theoros' and 'theoria' came from the word 'thea' means to look upon or view. Theoros was employed for observe the foreign cultural and religious rituals. Besides observation theoros was supposed to report back to his native city. Then theory can be seen as the intermediary among the events, the observer, and interpretations. Theory thus implies essentially linkable with observational reality and its interpretations (Vincent, 2007). Thiele (2002) observes, "Theories help us put the world in focus. What optical lenses do for our vision, theories do for our understanding. Whereas optical lenses improve our sight, theories improve our insight (p. 1)".

Theories are conceptual schemas that bring a world into clearer focus and allow us to better understand the world phenomena. Political theory represents "seeing" political phenomena in two senses. First, political theory provides a description of the political and second, political theory constitutes a form of aesthetic or religious vision. In the second sense political theory relates to the imaginative capacity of the theorist "an esemplastic" power that "forms all into once graceful intelligent whole" (Wolin, 2004, p. 17-18). Imagination is essential as no theorist does have the capacity to observe all political phenomena directly.

\section{DECODING THE PRACTICAL UTILITY OF POLITICAL THEORY IN CONTEMPORARY TIMES}

In early 1950s, during the conquest of behaviouralism, the death or decline of political theory was announced (for example, Laslett, 1956; Riemer, 1962; Easton, 1951). However, there is an ample literature which advocates that "either the death was prematurely diagnosed or that the wrong corpse was, in fact, identified" (Lawton, 1985, p. 16). At the onset of behavioural revolution in political science, however, there was growing dissatisfaction regarding the role of theory in mitigating various practical aspects of politics. The major criticism levied against theory was that due its excessive normativism and legalistic approach it was unable to provide practical solutions to the various occurring in the discipline. As a result, for a long time political theory is equated more with ethics and moral philosophy rather than understanding the problem solving aspects of theory. But it would really be an exaggeration to discern the positive role of theory in addressing multi-facets dimensions of politics. Following Thom Brooks 
(2015), we can argue that in spite of that growing skepticism against political theory, it is still very much relevant and serves several practical purposes of politics. According to Brooks political theory impacted politics significantly in three broad areas namely our thinking about politics, our thinking about public policy and through public engagement. Firstly, how we perceive and thinks about politics specifically our understanding of political decision making is more or less is greatly affected by theory. Theory guides us to understand about autonomy and consent, the nature of democratic governance as well as multiple identities and identity pertaining to political authority (Brooks, 2015). Secondly, if we think of public policy as a blueprint or process by which governments translate their visions into actions to improve the quality of its people, then in this aspect theory provides guidance by which best and optimal mean these visions can be transformed into reality. And lastly, political theorist played a catalytic role in shaping the forms of public engagement. Political theory helps in articulating consciousness among the common people about politics. For example, in recent times theorists use both old as well as new media to critically address the pressing issues of politics by engaging in discussion and deliberations thus helps in enlightening the common people about politics. Most importantly in contemporary times where common people are developing apathy about the issues of politics, political theory can play an important role in educating as well as help in increasing people participation in politics by guiding them about the nuances of politics. So from the above discussion it is very clear to coincide theory with abstract moral philosophy without any practical utility is essentially a misguided concept.

\section{POLITICAL ANALYSES IN THE ERA OF POST-FACTUAL POLITICS}

Starting from the ancient Greco-Roman periods and remain unchallenged till the emergence of positivist tradition, the traditionalism indeed highlights some vital aspects of politics and more or less discussed the core ideas of politics and political institutions like state, legislature, judiciary, justice, liberty, rights, etc. In spite of that one of the recurrent and very common criticism against traditionalism is that they were more of a lofty idealist, they prescribed more than accessing the practicality of politics. But at the same time we must admit that these ideas were the product of its own time when war and conflicts were the order of the day. Their recommendations were directed to how to achieve a perfect and just society. Traditionalism in the first half of the twenty first century was unable to save Europe from the devastation of the Great War; they failed to predict this event and at the same time incapable of finding the remedies, while at the same time there was a growing dissatisfaction among social scientists regarding its methodology. As a result, a new tradition emerged in social science - logical positivism that has its roots in Vienna Circle and the members were confident enough to discover the true task of the 'philosophy of science'. Logical analysis was its aim and subject matter was the positive and empirical sciences in which only 'meaningful' statements or the statements have cognitive significance are to be considered. Meaningful statements only in sense of being either analytic (self-contradictions) or synthetic (factual; subject to verified or falsified by evidence) in nature (Caldwell, 1994). It denies the metaphysical and ontological existence. But, in political science, that deals not merely with political practices of human beings within the domain of both state and society, but about the ontological dimensions of the political. The concept of verifiability or falsifiability is contested due the inherent nature of human beings. So accessing the human directions in politics in contemporary times, we must acknowledge that facts, truths, information all are highly contested issues and bounded by context. As human perceptions, ways of thinking and understanding differ from each other, the idea of universality of facts or truths are highly problematic. Take for an example those who supported the existence of state, may all agree that the first and foremost duty of the state is to upheld and protect the interests of individuals but there is not a single agreed definition that how it can be achieved, neo-liberals, communitarians, welfarist liberals have their own conception of delivering and securing the interests of individuals. These relative aspects of facts and truths must be kept in mind while referring any aspects of politics. The era of 'post-truth' politics creates a difficulty to find out what is truth as 'art of the lie' blurs not only the chasm between 'truth' and 'lie', but also places 'emotions' over the objective 'facts'. Usage of the term 'post-truth' appears recently in political context particularly after the Brexit referendum in 2016 and US presidential election in 2017 (McIntyre, 2018). Post-truth denotes the circumstances where political arguments rest much on emotions and beliefs rather than verifiable objective facts. It is being used for shaping the public opinion. It is also known as postfactual politics. 


\section{DEBATING POLITICAL THEORY: BEYOND EXCESSIVE EMPIRICISM AND EXTREME NORMATIVISM}

Over the years in the discourse of social sciences, especially in the study of politics, there are tendencies to separate theories, which are condemned to be more normative in nature, from the practical understanding of reality. This empirical-normative dichotomy leads to the 'mad craze' of implementing scientific tools in explaining politics is essentially misguided. Cox (1981) argues in this respect that this dichotomy is not simple as it seems every theorist intentionally or unintentionally brings certain values in their analysis. That is why he says, we must look closely into those ideas that claim themselves to be objective or value free and ask who or what is it for and what purpose does it serve. Pondering upon the need to resolve empirical-normative dichotomy or making a consolidation between the two, we may refer to the work of Amartya Sen. Sen (2009) falsifies the Rawlsian notion of justice on the ground that it is impossible to reach any society which is 'perfectly just'. He, therefore, calls for an alternative notion to find out that society which is comparatively 'less unjust'. He quests for 'removal of injustice' instead of making the institutions 'perfectly just' (Sen, 2009). While Sen falsifies Rawlsian notion of justice, the question arises does Sen totally adopt a philosophical method to understand the causes of injustice, like famine, hunger, malnutrition, etc., in the third world countries? Rather he categorically rests on an ample size of empirical or factual data that shapes his understanding on the idea of justice. In social sciences our focus should not be confined only to problems identification but solutions of these problems are essentially important one. It is often been said, political philosophy prescribes more than tries to identify the solutions of the problems but we should keep in mind when we problematise something we must have certain conceptions or theories, and also we recommend some solutions with the help of 'what ought to be'. We tend to focus more on data or information while looking at solutions. But in order to rightly assess the problems and to provide solutions we need to have definite conceptual understanding of the problems and this conceptual understanding is undoubtedly value laden. So if we adopt problem solving approach in social sciences it links values and facts. Thiele (2002) holds that theories work well only when they efficiently deal with and make a tie between the received information and conceptual networks. Too little data or a scarcity of conceptual linkages lead to an underexposed image of the world. Information is required for the foundation of theory, at the same time too much data leads to an overexposed image of the world. The normative standard enables us to reject the unnecessary facts and accept the necessary facts. While we protest against the human rights violation of a particular community, we should have the prerequisite knowledge on 'what is human rights?', 'why do we need it?', 'how it can be violated?', 'how can we say this exact event as human rights violation?'. Here the last question is based on empirical enquiry while the rest are conceptual and normative. Similarly, when we speak of administrative corruption, we know well that the crisis of ethics in administration leads to a corrupt administration. We simultaneously apply concept and use data to prove it that why we can mark the particular incident as corruption. After identifying something as corruption we look forward to employing some necessary actions for removing or at least reducing it grounded on 'what ought to be'. Though some authors like Ball (1995) opines that there should not be any 'perennial questions' in politics since the moral languages responsible for framing the questions are not historically transcendental, but some of the theorists opined that philosophical enquiry brings the issues like 'what is justice?', 'what is liberty?', 'why should we obey the state?', closely in our focus which are the 'perennial questions' in politics (Robins, 1985), and these remain important over the time because these are, we do believe, the foundations of the human world as well as retain the essence of 'the political'. Political philosophy is not merely for description and prescription rather the task of the political philosophers is to identify problems and finding out the ways by means of which we can get rid of these problems more efficiently. The more discrepancy between 'what is' and 'what ought to be', the more challenge to ensure a good life to the people. Reus-Smit and Snidal (2008) rightly observe this tendency of isolating normative and empirical dimensions in international relations theories has been very much problematic because every international relations theory, be it realism, or liberalism, or alternative theories like feminism, constructivism, or postmodernism, have a strong normative outlook of world politics on the basis of which they visualise the world of 'what is'. For example, when classical realism emphasises on the national interest, and balance of power, and so on, as the core of world politics, all of which are essentially value laden and on the basis of these values the classical realists visualise how the world politics should be directed or organised. In international relations and foreign policy studies, how can we make use of the facts and what type of possible predictions will come from it - both are essentially determined by how we interpret and understand the world (Viotti \& Kauppi, 2012). We therefore must say that the human world keeps on both the empirical and normative dimensions in a cyclic, parallel, or even in interpenetrative order. So, it is impossible to make a separation between empiricism and normativism because of their interpenetrative nature.

International Journal of Research -GRANTHAALAYAH 


\section{POLITICS AS ABSENCE OF GENERAL AGREEMENT}

Human mind is not seen through that what is playing one's own mind. We can say it a 'hidden performing organ'. It can only be understood not by seeing the activities but systematic mind reading and calculative analysing of mind game, but still it is a difficult task. The past cumulative instances are helpful to make a sense on the present. But prediction is to large extent impossible because human nature is hardly unattainable and unpredictable. Human beings are political because they are self-conscious and self-calculative. This political nature makes human beings unique from the rest of the animals in the world. Human beings tend to think themselves as a unique individual among the group of individuals and act self-consciously not only for the groups, but also for one's own self. Human beings are always rational as they all are utility maximizers. Being a utility maximizer, human beings always evaluate their ends and means. If they found trouble with existing arrangements they postpone, change, or even deny their ends and means. Human beings are also political because of their diverse and contested self-interests. It would not be exaggerated to say that one of the common and recurrent features which can be found in social sciences in general and political science in particular is that they all deal with the idea of absence of general agreement. Disagreement is not an anomalous phenomenon, it comes inherently due to the diverse and complex human behaviour that develops because of our diverse value system and our contrasting preferences, choices, which make human beings unique in the sense that they may see the same phenomenon but interpret it differently from one another because of their different value preferences. This idea of absence of general agreement, we do believe, shapes and constitutes the core of 'the political' that manifests through the practices called 'politics'. In order to become any phenomena to be a theme of discussion in political science there must be a great deal of disagreements and contrasts regarding its nature and its content. For an example, we may ask, is there any necessity and viability of state? Is it possible for the utmost development of individual without any central political institution that commands and also which is the supreme authority for resolving the conflict arises in society? For the classical Marxists, and anarchists, it is possible and even desirable to lead a good and happy life without any repressive, controlling, and commanding authority. The neo-liberals also shouted for some sort of diminution of state and promotion of market. They more or less, in their own way, took politics as an arena to move from conflict to develop cooperation. But the desirability of the state or any other central political mechanism arises due to resolve the conflict arises from the antagonistic nature of attitudes and behaviours which is an innate characteristic of human beings.

Nevertheless, an ample amount of definition of politics, we can say that politics is a state of affairs arises from the absence of general agreement. General agreement is hardly possible since human beings have different types of contradictory thinking, conflict over the resources, even not only conflict over the material things but also conflict in establishing one's own will over the others. Absence of general agreement leads to conflict, struggle for power, exclusion, dominance, coercion, resistance, and so on and so forth. For that particular reason politics is everlasting. If we will be going to address in a better and convincing way all the things, we have to rest on the conceptual schema or theory. Here political theory implies because unless the normative framework, we cannot explain the set of practices which is called politics. This essentially contrasting value systems, preferences, norms of human beings what make the understanding of 'the political' and the study of politics difficult to completely adopting the methods and techniques, unlikely of natural sciences, in reaching to a final conclusion evading the 'logic of contestability'.

\section{CONCLUSION}

The basic question that we explore and understand in this study is how to make political theory more practical as a discipline in contemporary times. In this contemporary era of alternative facts, theory helps us in three ways firstly, to differentiate among several alternative facts; secondly, to focus on the facts which are helpful; and thirdly, theory may be helpful as different theories may deal with the same phenomenon but arrive at different conclusions. Here practicality does not imply complete detachment or altogether rejection of either normative or empirical aspects of politics rather an amalgamation between the two. Neither excessive empiricism nor extreme normativism is sufficient to evaluate 'the political' nature of human beings. But it is also true this amalgamation is something of a herculean task especially in the current context due to our inclination of separating normative and empirical aspects of politics. But we must say that 'politics', both as a discipline and practice, changes over the time; it transforms its contents and adopts different methodologies to make the discipline more effective to address the ever-changing nature of politics as a set of practices in the milieu of contestability constituted by 'the political' 
Revisiting Political Theory: Beyond Excessive Empiricism and Extreme Normativism

\section{SOURCES OF FUNDING}

This research received no specific grant from any funding agency in the public, commercial, or not-for-profit sectors.

\section{CONFLICT OF INTEREST}

The author have declared that no competing interests exist.

\section{ACKNOWLEDGMENT}

None.

\section{REFERENCES}

[1] Ball, T. (1995). Reapprising political theory: Revisionist studies in the history of political thought. New York, NY: Oxford University Press.

[2] Bhargava, R. (2012). What is political theory and why do we need it? (Paperback ed.). New Delhi, India: Oxford University Press.

[3] Brooks, T. (2015). Why political theory matters. In G. Stoker, J. Pierre, \& B. G. Peters (Eds.), The relevance of political science (pp. 136-146). Basingstoke, England: Palgrave Macmillan.

[4] Caldwell, B. J. (1994). Beyond positivism (Revised ed.). London, England: Routledge.

[5] Cobban, A. (1953). The decline of political theory. Political Science Quarterly, 68(3), 321-337. http://doi.org/10.2307/2145603

[6] Cox, R. W. (1981). Social forces, states and world orders: Beyond international relations theory. Millenium Journal of International Studies, 10(2), 126-155. http://doi.org/10.1177/03058298810100020501

[7] Easton, D. (1951). The decline of modern political theory. The Journal of Politics, 13(1), 36-58. http://doi.org/10.2307/2126121

[8] Heidegger, M. (1962). Being and time. (J. Macquarrie, \& E. Robinson, Trans.) Oxford, England: Blackwell.

[9] Husserl, E. (1970). The crisis of european sciences and transcendental phenomenology: An introduction to phenomenological philosophy. (D. Carr, Trans.) Evanston, IL: Northwestern University Press.

[10] Laslett, P. (Ed.). (1956). Philosophy, Politics and Society. New York: The Macmillan Company.

[11] Lawton, A. (1985). Political theory. In L. Robins (Ed.), Introducing Political Science: Themes and Concepts in Studying Politics (pp. 16-25). New York, NY: Longman.

[12] Lekka-Kowalik, A. (2010). Why science cannot be value-free. understanding the rationality and responsibility of science. Science and Engineering Ethics, 16(1), 33-41. http://doi.org/10.1007/s11948-009-9128-3

[13] Mahajan, G. (2011). Explanation and understanding in the human sciences (3rd ed.). New Delhi, India: Oxford University Press.

[14] Makkreel, R. A., \& Rodi, F. (Eds.). (1996). Wilhelm Dilthey selected works (Vol. IV). (R. A. Makkreel, \& F. Rodi, Trans.) Princeton, NJ: Princeton University Press.

[15] McIntyre, L. (2018). Post-truth. Cambridge, MA: MIT Press.

[16] Mouffe, C. (2005). On the political. London, England: Routledge.

[17] Reus-Smit, C., \& Snidal, D. (2008). Between utopia and reality: The practical discourses of international relations. In C. Reus-Smit, \& D. Snidal (Eds.), The Oxford Handbook of International Relations (pp. 3-37). New York, NY: Oxford University Press.

[18] Riemer, N. (1962). The Revival of Democratic Theory. New York: Appleton-Century-Crofts.

[19] Robins, L. (1985). An introduction to political science. In L. Robins (Ed.), Introducing Political Science: Themes and Concepts in Studying Politics (pp. 1-15). New York, NY: Longman.

[20] Sen, A. (2009). The idea of justice. Cambridge: Harvard University Press.

[21] Strauss, L. (1988). What is political philosophy? And other studies (Reprint ed.). Chicago, IL: The University of Chicago Press. 
[22] Thiele, L. P. (2002). Thinking politics: Perspectives in ancient, modern, and postmodern political theory (2nd ed.). New York, NY: Chatham House Publishers.

[23] Vincent, A. (2007). The nature of political theory (Paperback ed.). New York, NY: Oxford University Press.

[24] Viotti, P. R., \& Kauppi, M. V. (2012). International relations theory (5th ed.). Boston, MA: Pearson.

[25] Weber, M. (1949). Max Weber on the methodology of the social sciences. (E. A. Shils, H. A. Finch, Eds., E. A. Shils, \& H. A. Finch, Trans.) Glencoe, IL: The Free Press.

[26] Wolin, S. S. (2004). Politics and vision: Continuity and innovation in Western political thought (Expanded ed.). Princeton, NJ: Princeton University Press. 